Dicle Üniversitesi Veteriner Fakültesi Dergisi
https://dergipark.org.tr/tr/pub/duvetfd
Araştırma Makalesi/Research Article
Dicle Üniv Vet Fak Derg 2021;14(2):118-121
DOI: 10.47027/duvetfd. 983490

\title{
Studies on Arteria Celiaca and Its Branches in Gurcu Goat
}

\author{
Semine DALGA ${ }^{1, a, 凶}$, Ümran YAMAN ${ }^{1, b}$, Tansel ÇAL ${ }^{1, c}$ \\ ${ }^{1}$ Department of Anatomy, Faculty of Veterinary Medicine, Kafkas University, Kars, TÜRKIYE \\ aORCID: 0000-0001-7227-2513; bORCID: 0000-0003-3762-8945; 'ORCID: 0000-0002-3034-5814
}

\begin{tabular}{ccc}
\hline Geliş Tarihi/Received & Kabul Tarihi/Accepted & Yayın Tarihi/Published \\
16.08 .2021 & 18.10 .2021 & 31.12 .2021 \\
\hline
\end{tabular}

\begin{abstract}
In this study, arteria celiaca and its branches of Gurcu goats were examined macroscopically. 6 Gurcu goats (3Female/3Male) were used in the study. Latex was injected into the study materials from arteria carotis externa. In one of the male Gurcu goats, arteria celiaca was found to be separated from the aorta abdominalis by a common root with arteria mesenterica cranialis. It was determined that 3 branches were separated from arteria celiaca in one of the female Gurcu goats.

It was observed that arteria celiaca, which separated from the ventral aspect of the aorta abdominalis, divided into 2 branches in animals. It was observed that arteria lienalis, a relatively thin branch, first gave rami pancreatici to the pancreas, then ramus epiploicus, arteria ruminalis sinistra and arteria ruminalis dextra. In females, it was observed that the arteria lienalis divided into 2 branches and entered the spleen from the hilus lienis. It was determined that the other branch coming out of arteria celiaca was a root belonging to arteria hepatica and arteria gastrica sinistra. In this study, arteria celiaca and its branches were examined macroanatomically in Gurcu goats and their vascular variations were compared with other small ruminants.
\end{abstract}

Key Words: Anatomy, Celiac artery, Gurcu goat

Gürcü Keçilerinde Arteria Celiaca ve Dalları Üzerinde Araştırmalar

Öz

Bu çalışmada, Gürcü keçilerinin arteria (a.) celiaca ve dalları makroskobik olarak incelendi. Araştırmada 6 adet Gürcü keçisi (3Dişi/3Erkek) kullanıldı. Çalışma materyallerine a. carotis externa'dan latex enjeksiyon edildi. Erkek Gürcü keçilerinin bir tanesinde a. celiaca'nın a. mesenterica cranialis ile ortak bir kök ile aorta abdominalis'ten ayrıldığı görüldü. Aorta abdominalis'in ventral yüzünden ayrılan a. celiaca'nın tüm hayvanlarda 2 dala ayrıldığı gözlendi. Nispeten ince bir dal olan a. lienalis'in ilk olarak pancreas'a giden rami pancreatici'yi verdiği daha sonra ramus epiploicus, a. ruminalis sinistra ve a. ruminalis dextra isimli dallarını verdiği gözlendi. Dişilerde a. lienalis'in 2 dala ayrılarak hilus lienis'ten dalağın içerisine girdiği gözlendi. A. celiaca'dan çıkan diğer dalın a. hepatica ve a. gastrica sinistra'ya ait bir kök olduğu tespit edildi. Yapılan bu çalışma ile Gürcü keçilerinde a. celiaca ve dallarının makroanatomik olarak incelenmiş olup damar varyasyonları diğer küçük ruminantlar ile karşılaştırılmıştır.

Anahtar Kelimeler: Anatomi, Arteria celiaca, Gürcü keçisi

\section{GiRiş}

Gurcu goats (Capra falconeri) originating from the Caucasus, also known as Tbilisi goat or Caucasian goat, are bred in Northern Anatolia, especially in Kars province and Çıldır district of Ardahan (Figure 1). The Gurcu goat, which is mostly black, gray and white in color, originates from the auger horned goat Capra falconeri and may show similarities with the Abaza goats bred especially in the Şavşat or Borçka region $(1,2)$.

Arteria celiaca, at the level of the last thoracal and first lumbar vertebra (3-6) or the 1st and 2nd lumbar vertebrae $(7,8)$, just before the origin of arteria mesenterica cranialis, it emerges from the ventral wall of abdominal aorta. Some authors (9-11) reported that this vessel can originate by forming a common root with the arteria mesenterica cranialis. Arteria celiaca supplies three main branches, arteria gastrica

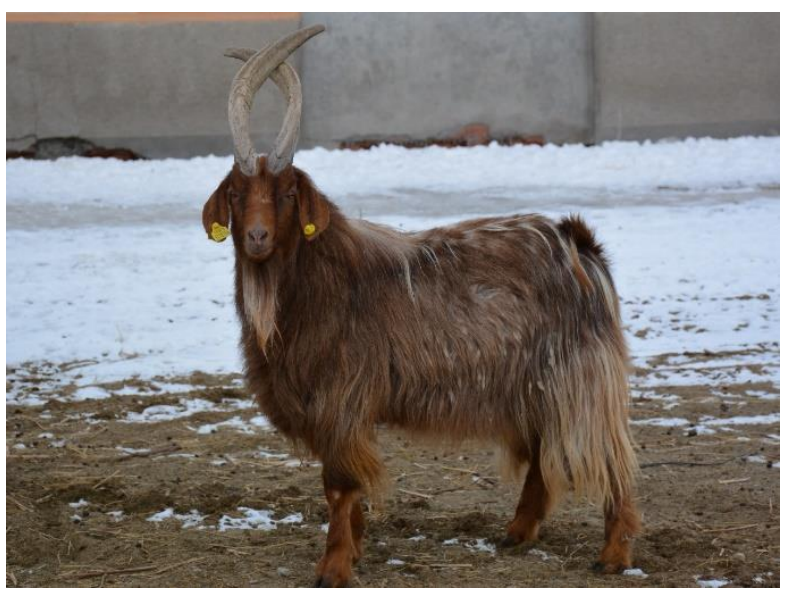

Figure 1. Male Gurcu goat 
sinistra, arteria hepatica and arteria lienalis, and supplies the initial part of the liver, spleen, pancreas, stomach and duodenum (3,9,12-14). In some animal species, it has been stated that arteria celiaca gives two branches as arteria hepatica and arteria lienalis $(15,16)$. Although there have been studies on the anatomy of arteria celiaca in some small ruminants, domestic and wild animals $(4,5,9-10,17-21)$ no studies on arteria celiaca were found in Gurcu goats, which is the native breed of Turkey. In this study, it was aimed to examine the arteria celiaca and its branches macroanatomically in Gurcu goats.

\section{MATERIALS AND METHODS}

In the study, 6 Gurcu goats (3Female/3 Male), which were in the farm of the Faculty of Veterinary Medicine of Kafkas University and could not produce fertile offspring, were used. Animals were deeply anesthetized with Xylazine hydrochloride $(0.25 \mathrm{mg} / \mathrm{kg}$ intravenous) and cloralhydrate $(20 \mathrm{mg} / \mathrm{kg}$ intraperitoneally). The skin was dissected from the upper $1 / 3$ of the neck on the right side of 6 Gurcu goats, who were anesthetized, and their blood was drained from the arteria carotis communis dextra. Following this procedure, latex colored with red dye was injected into the entire arterial system from the arteria carotis communis dextra. The materials were kept in the refrigerator for 4 days for latex solidification. Afterwards, the animals were dissected appropriately

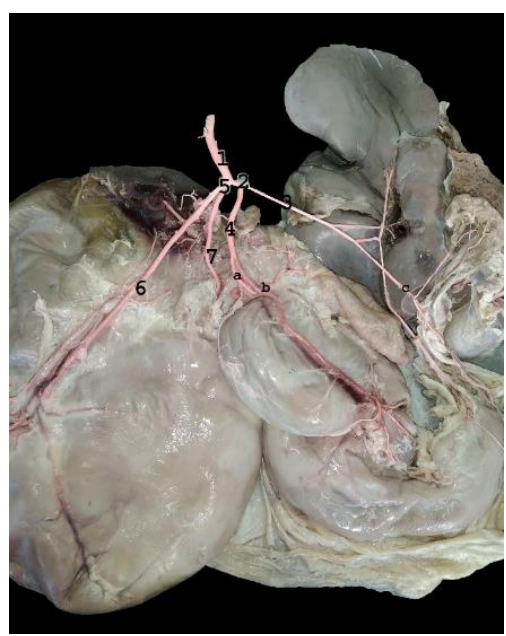

Figure 2. Arteria celiaca and branches in male Gurcu goats

1. A. celiaca, 2. Common root of a. hepatica and a. gastrica sinistra, 3. A. hepatica, 4. A. gastrica sinistra, 5. A. lienalis, 6. A. ruminalis sinista, 7. A. ruminalis dextra, a,b. Continuation of left gastric artery, c. left gastric artery with the right gastric artery.

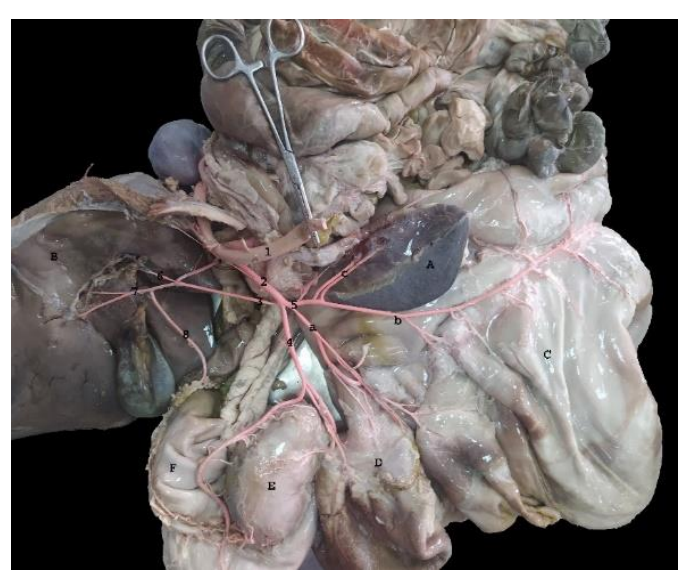

Figure 3. A. celiaca and last branches in female Gurcu goats

1. Aorta abdominalis, 2. A. celiaca, 3. A. hepatica, 4. A. gastrica sinistra, 5. A. lienalis, 6. Ramus sinister, 7. Ramus dexter, 8. A. gastrica dextra, a. Continuation of left gastric artery, b. A. ruminalis sinista, c. a. lienalis, A. Lien, B. Hepar, C. Rumen, D. Reticulum, E. Omasum, F. Abomasum and the arteria celiaca and the organs it fed were removed and fixed in $10 \%$ formaldehyde solution for one week. After fixation, arteria celiaca and its branches were dissected and findings were obtained. The relevant vessels were named. The terms used in the study were based on Nomina Anatomica Veterineria (22). Ethical permission for the study was obtained from the Ethics Committee of the KAFKAS Veterinary Faculty (KAÜ/HADYEK, Aprroval no: 2021/122).

\section{RESULTS}

It was seen that arteria celiaca was separated from the ventral aspect of the aorta abdominalis, which passes from the thoracic cavity to the abdominal cavity via the hiatus aorticus, at the level of the first lumbar vertebra. After the arteria celiaca separated from the abdominal aorta, it was observed that it progressed $8-10 \mathrm{~cm}$ in females and $6-8 \mathrm{~cm}$ in males and divided into 2 branches in materials. It was determined that one of the branches was arteria lienalis and the other branch was the common branch of arteria hepatica and arteria gastrica sinistra (Figure 2). Arteria gastrica sinistra was found to be thicker than arteria hepatica (Figure 2, 3, 4). It was seen that 3 branches were separated from arteria celiaca in one of the female Gurcu goats (Figure 3). In one of the male animals, arteria celiaca was seen to separate as a common root with arteria mesenterica cranialis (Figure 4). 
seen to be the continuation of arteria lienalis. It was seen that the vein running in the sulcus longitudinalis dexter gave various branches scattered on the visceral surface of the rumen.

It was determined that arteria gastrica sinistra was separated from arteria celiaca with arteria hepatica by a common root. It was observed that arteria gastrica sinistra, which is quite thick compared to arteria hepatica, divided into 2 branches approximately $8-10 \mathrm{~cm}$ after its course. It was seen that the arteria gastrica sinistra first gave the arteria reticularis, then the arteria gastro epiploica, and then ended by anastomosis with the arteria gastrica dextra.

It was observed that arteria hepatica was separated from arteria celiaca by a common root with arteria gastrica sinistra. It was seen that the first rami pancreatici was given 5-7 cm after the arteria hepatica started its course. In the course of arteria hepatica towards porta hepatis, it was seen that it gave branches first ramus dexter, then ramus sinister and arteria cystica. It was observed that the continuation of the vein was the arteria gastroduodenalis and this vein coursed in the curvatura minor of the abomasum. It was determined that the vessels separated from the arteria celiaca provided arterial vascularization of the stomach, spleen, pancreas, liver, gallbladder and the beginning parts of the duodenum.

\section{DISCUSSION AND CONCLUSION}

It was determined that arteria celiaca was separated from the ventral surface of the aorta abdominalis, which passes from the thoracic cavity to the abdominal cavity via the hiatus aorticus, at the level of the 1st lumbar vertebra. They stated that arteria celiaca is the first branch of the aorta abdominalis in some sheep $(17,23)$ and goat species $(24,25)$ studied in the literature. For the level where arteria celiaca separates from the aorta abdominalis, Ozudogru et al. 2019 (18), Dursun 2005 (3) and Turkmenoğlu 1996 (5) stated that its left the last thoracal and first lumbar vertebrae. Alsafy (2009) and El Gendy (2007) reported that the goat also separated from the 1 st and 2 nd lumbar vertebrae. This situation is similar to Gurcu goats.

Some researchers in the literature $(4,7,9,10,11)$ stated in some of their study materials that arteria celiaca splits from the aorta abdominalis as a common root with arteria mesenterica cranialis. Same situation was seen in one of the male Gurcu goats.

Maala et al. (1988) studying on the branching of arteria celiaca in goats, reported that the branching was in 6 different ways, in one of them arteria gastrica sinistra and arteria hepatica came out as a common root. Ozudogru et al. 2019 and Turkmenoglu (1996), reported that in 3 of their materials, the arteria gastrica sinistra and arteria hepatica were separated by a common root they working in sheep. In Gurcu goats, arteria gastrica sinistra and arteria hepatica were separated from arteria celiaca by a common root.

In other studies available in the literature, it has been reported that arteria lienalis, arteria gastrica sinistra and arteria hepatica from arteria celiaca are divided into 3 separate branches $(4,9,10,12-14)$. Some researchers have stated that arteria lienalis, arteria hepatica, arteria gastrica sinistra and arteria ruminalis sinistra are separated from arteria celiaca $(7,23,27)$.

It has been reported for sheep (23), goat (7) and buffalo (11) that arteria lienalis separated from arteria celiaca ends in the spleen after giving ramus epiploicus, arteria ruminalis sinistra and arteria ruminalis dextra. In Gurcu goats, arteria lienalis was observed to give branches named rami pancretici after separating from arteria celiaca. After giving ramus epiploicus and arteria ruminalis sinistra, it was observed that it gave 2 branches for the spleen in females and a single branch in males, and entered the hilum of the spleen approximately $5-7 \mathrm{~cm}$ after its course. The continuation of the vessel was found to be arteria ruminalis dextra.

In studies conducted in sheep $(17,18,28)$ it was stated that arteria gastrica sinistra is the thickest vessel as a continuation of arteria celiaca. In addition, this situation has also been reported in goats (24). Consistent with the literature, it was observed that arteria gastrica sinistra was the thickest vessel in Gurcu goats.

Consistent with the literature $(7,18,29)$, it was observed that arteria cystica originates from arteria hepatica in Gurcu goats, and ends up in the vesica fellea, where travels into go on the visceral surface of the liver.

As a result, arteria celiaca and its branches were compared in terms of gender in Gurcu goats. Although there were differences between the sexes, noticeable variations were also noted between individuals of the same sex. Vascular similarities and differences were compared both within the species and with other species.

\section{CONFLICT OF INTEREST}

The authors declare no conflicts of interest with respect to the publication of this manuscript.

\section{ACKNOWLODGMENT}

This study was made from the project materials, which were stored under appropriate conditions, supported by the Scientific Research Projects Directorate of KAFKAS University as the project numbered "2019-TS-16".

\section{REFERENCES}

1. Batu S. (1951). Turkey goat breeds. Ankara University Faculty of Veterinary Medicine Publications, Ankara.

2. Sezgin E, Kopuzlu S, Yüksel S. (2010). Abaza keçisi. Ulusal Keçicilik Kongresi, Çanakkale; pp. 241-244.

3. Dursun N. (2005). Veteriner Anatomi II. 11. Baskı, 128-63, Medisan Yayınevi, Ankara.

4. Karadag H. (1988). The anatomical comparative study on the celiac artery and its branches in Akkaraman sheep and ordinary goat. J Vet Sc, 12, 196-204.

5. Türkmenoğlu i. (1996). Akkaraman Koyunu ve Ankara Keçisinde karın boşluğu arterleri üzerinde karşılaştırmalı makroanatomik araştırmalar. Selçuk Üniversitesi. Sağlık Bilimleri Enstitüsü, Türkiye.

6. Demiraslan Y, Orhun Dayan M. (2021). Veteriner Sistematik Anatomi, Atlas Kitabevi, 1. Basım Mayıs 2021

7. Alsafy M. (2009). Celiac trunk and the variability of its branches in goats. J App Biolog Sci, 3, 65-70. 
8. El Gendy SAA. (2007). Surgical anatomical approach of the abdomen in the goat. PhD thesis, Faculty of Veterinary Medicine, Alexandria University, Alexandria

9. Karmona KH, Kovachev G. (1985). Variability of the celiac artery and its branches in sheep. Vet Med Nauki, 22, 31-37.

10. Langenfeld M, Pastea E. (1977). Anatomical variants of the celiac artery in the sheep, with special reference to the celiomesenteric arterial trunk. Anat Anz, 142, 168-174.

11. Machado F, Miglino A, Didio A, Oliveira Borges C. (2002). The arterial supply of buffalo stomachs (Bubalus Bubalis). Buffalo J, 18, 257-265.

12. Dyce KM, Sack WO, Wensing CJG. (1987). Text Book of Veterinary Anatomy. W.B. Saunders Company, Philadelphia.

13. McCarthy PH. (1984). Transruminal palpation of abdominal arteries of the permanently fistulated dairy cow. Am J Vet Res, 45, 1632-1637.

14. Smuts MMS, Bezuidenhout AJ. (1987). Anatomy of the Dromedary. Clarendon press, Oxford.

15. Yılmaz S, Atalar O, Aydin A. (2004). The branches of the arteria celiaca in badger," Indian Vet J, 81, 183-187.

16. Atalar O, Yilmaz S. (2004). The branches of the arteria celiaca in the porcupine (Hystrix cristata)," Vet Med-Czech, 49, 52-56.

17. Mohamed R, Adogwa A, Driscol M, Rampersad S. (2016). Arterial supply of the stomach of the barbados black belly sheep in Trinidad. Int J Vet Sci, 5, 142-147.

18. Özüdoğru Z, Özdemir D, Balkaya H, Kara H. (2019). Konya Merinosunun Arteria Celiac'ası ve Dalları Üzerine Makroanatomik Bir Çalışma. Atatürk Üniversitesi Vet. Bil. Derg. 14(1): 45-51, 2019. DOI: 10.17094/ataunivbd.425567

19. Özdemir D, Özudogru Z, Balkaya H, Kara H. (2020). Hasmer Koyununda Arteria Celiaca ve Dallarının Makroanatomik Incelenmesi, Atatürk Üniversitesi Vet. Bil. Derg; 15(2): 100-105, DOI: 10.17094/ataunivbd.663691

20. Gürbüz I, Dayan MO, Demiraslan Y, Aslan K. (2017). Malakan Atı'nda arteria celiaca ve dalları üzerinde makroanatomik araştırmalar, Eurasian J Vet Sci, 33, 3, 133-137 DOI: 10.15312/EurasianJVetSci.2017.149.
21. Kırbaş Doğan G, Dalga S, Akbulut Y, Aslan K. (2019). Kızıl Tilkilerde (Vulpes vulpes) Arteria Celiaca ve Dalları Üzerinde Bir ÇaIışma. Harran Üniv Vet Fak Derg; 8 (2): 168-172.

22. Anonymous., 2012. Nomina Anatomica Veterinaria, 5th. Ed. Copyright by the World Association of Veterinary Anatomists.

23. Balkaya H, Özüdoğru Z, Özdemir D. (2017). Güney Karaman koyununda arteria celiaca ve dallarının makroanatomik yapısı. I. Uluslararası Türkiye Veteriner Anatomi Kongresi \& X. Ulusal Veteriner Anatomi Kongresi 13-16 Eylül 2017, Sandıklı/Türkiye.

24. Mohamed R, Adam Z, Gad M. (2017). Arterial supply of the stomach of the Egyptian native goat. J Adv Vet Anim Res, 4, 80-87.

25. Youssef GA. (1991). Some anatomical studies on the coeliac, cranial mesenteric and caudal mesenteric arteries of goat. PhD Thesis, Faculty of Vet. Med. Moshtohor, Zagazig University; Benha, Egypt.

26. Maala CP, Reyes EV, Ducusin RJ. (1988). Some contributions to the anatomy of the arterial supply to the stomach of the goat. Philipp J Vet Med, 25, 47-52.

27. Perez W, Vazques N, Ungerfeld R. (2016). Arterial vasularization of the gastrointestinal tract of the pampas deer. Anat Histol Embryol, 45, 240-245.

28. Boccaletti D, Borelli V. (1981). Ramification of the celiac artery in sheep of Corriedale race. Belo Horizonte, Minas Gerais, Brasil, Sociedade Brasileria de Anatomia, pp: 47- 48.

29. Getty R, Sisson and Grossman's. (1975). The Anatomy of the Domestic Animals, Saunders, Philadelphia; Pa, USA, 5thedition.

$\square$ Corresponding Author:
Semine DALGA
Department of Anatomy, Faculty of Veterinary Medicine,
Kafkas University, Kars, TÜRKIYE
E-mail: sdalga91@gmail.com

